\title{
Impact Of Teacher's Behaviour On The Academic Achievement Of University Students
}

Syed Shafqat Ali Shah, PhD, University Institute of Education and Research, University of Arid Agriculture, Pakistan

\begin{abstract}
This research article discusses the impact of teacher's behaviour on the academic achievement of university students. All the teachers and students of public sector universities constituted the population. From the 15 public sector universities, 375 teachers and 1500 students from five departments were selected as a sample. Two questionnaires were developed and validated through pilot testing and administered to the sample for the collection of data. The researcher personally visited respondents, thus 100\% data were collected. The collected data were tabulated and analyzed by using chi-square and Pearson's product moment coefficient of correlation (r). The major conclusions of the study were that teachers felt proud to be teachers, they adjusted themselves with the prevailing situation and circumstances, and they used different motivational techniques for teaching. Students were found to be satisfied with the positive behaviour of their teachers. The relationship between the teachers' behaviour and corresponding academic achievement (marks) revealed a highly positive significant correlation.
\end{abstract}

\section{INTRODUCTION}

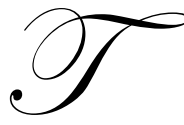

he impact of teacher's behaviour plays an important role in the academic achievement of students. Behaviour is a description of the observable outcome of teacher and student performance in different activities of institutions. Behaviour may be positive or negative and effective or ineffective. The main purpose of this study was to investigate the impact of teachers' behaviour on the academic achievement of university students.

The meaning of behaviour is to conduct or carry oneself or behaviour in what we do, especially in response to outside stimuli (UNESCO, 1986); anything that an organism does that involves action and response to stimulation (UNESCO, 1986).

Behaviour is an observable, identifiable phenomenon (Joyce, 1980). Teachers also need to be thoughtful in the way in which they react to students' comments. Generally, teachers react by using praise, acceptance, remediation, or criticism in responding to students (Derk, 1974).

Teaching is an arrangement and manipulation of a situation in which there are gaps or obstructions and where an individual tries to overcome the problem from where he learns (Iqbal, 1996). Teachers and administrators of all categories and levels should be aware of the roles played by them in the present context of education. They should understand that their roles and behaviours are not fixed, but are revolving around the influence of changes taking place in a society and the educational system itself (UNESCO, 1975). Behaviour is a response which an individual shows in his environment at different times (Taneja, 1989).

Academic achievement has been variously defined as a level of proficiency attained in academic work or as formally acquired knowledge in school subjects, which is often represented by percentage of marks obtained by students in examinations (Kohli, 1975). Researches have shown that besides being the criteria of promotion to the next class, academic achievement is an index of all future successes in life. Superior achievers in the academic 
world generally also tend to maintain their level of achievement in the occupational field. Moreover, Reis et al. (1984) reported that academic achievement also has a significant effect on self-evaluation of learners. To reach the goal of excellence in the academic sphere, and to optimize academic achievement to a maximum, a review of academic achievement and its implications for educationists and policy makers would be meaningful.

A formal beginning to explore the determinants of academic achievement as made with Binet's attempts to predict children's academic achievement from their intelligence scores. There is overwhelming evidence establishing intelligence as the most significant predictor of academic achievement (Karnes et al., 1984). Thorndike (1963) pointed out exact correspondence between intelligence and achievement.

Some studies have been done to relate cognitive style with academic achievement. Field independent subjects were found to be higher on achievement than field dependent subjects (Holper and Helen, 1986). Academic achievement was enhanced the most by use of three socializing agents (peers, teachers and parents) to reinforce academic behavior. Reinforcement using all three agents was the most effective way to improve achievement (Gauthier et al., 1984).

\section{STATEMENT OF THE PROBLEM}

The purpose of the study was to examine the academic achievement of the university students as a result of the teacher's behaviour.

\section{PROCEDURE OF THE STUDY}

The sample consisted of 375 teachers and 1,500 students of public sector universities in Pakistan. Two questionnaires were used with a five-points rating scale in order to collect the views of university teachers and students about the teachers' behaviour regarding academic achievement of the students. The researcher personally visited 15 public sector universities and collected views regarding behaviour of teachers on academic achievements of students. The collected data were analyzed by using Chi square and Pearson product movement co-efficient of correlation (r).

\section{RESULTS}

Table 1 below shows that $\mathrm{x}^{2}$ values of the responses of teachers are greater than the table values at 0.05 level of probability. Hence, all the statements are accepted. Analysis of Table 1 of the teacher's intention showed that the teacher related the subject matter to the lives of the students. They adjusted themselves with the prevailing situations and circumstances and strived for continuous improvement in their knowledge and skills. They also used different evaluation techniques while teaching. They awarded marks fairly and also participated in co-curricular activities. Teachers focused on character building of the students. 
Table 1: Responses of Teachers

\begin{tabular}{|c|c|c|c|c|c|c|c|c|}
\hline \multirow{3}{*}{$\begin{array}{l}\text { Teachers feel proud to be called as } \\
\text { teacher. }\end{array}$} & & SA & $\mathbf{A}$ & UD & DA & SDA & Total & $x^{2}$ \\
\hline & Responses & 313 & 62 & - & - & - & 375 & \multirow{2}{*}{$982.5^{*}$} \\
\hline & Percentage & 83.46 & 16.53 & & & & 100 & \\
\hline \multirow{2}{*}{$\begin{array}{l}\text { Teachers adjust him/her self with } \\
\text { prevailing situation and circumstances } \\
\text { of university. }\end{array}$} & Responses & 156 & 194 & 25 & - & - & 375 & \multirow{2}{*}{$459.62 *$} \\
\hline & Percentage & 41.6 & 51.73 & 6.66 & - & - & 100 & \\
\hline \multirow{2}{*}{$\begin{array}{l}\text { Teachers strive for continuous } \\
\text { improvement in their knowledge and } \\
\text { skills }\end{array}$} & Responses & 233 & 142 & - & - & - & 375 & \multirow{2}{*}{$617.7^{*}$} \\
\hline & Percentage & 62.1 & 37.86 & - & - & - & 100 & \\
\hline \multirow{2}{*}{$\begin{array}{l}\text { Teachers make the teaching effective } \\
\text { with different teaching techniques. }\end{array}$} & Responses & 171 & 204 & - & - & - & 375 & \multirow{2}{*}{$569.76^{*}$} \\
\hline & Percentage & 45.6 & 54.4 & - & - & - & 100 & \\
\hline \multirow{2}{*}{$\begin{array}{l}\text { Teachers listen to the students with } \\
\text { patience and tolerance and guide } \\
\text { students in spare time. }\end{array}$} & Responses & 269 & 106 & - & - & - & 375 & \multirow{2}{*}{$739.62 *$} \\
\hline & Percentage & 71.73 & 28.26 & - & - & - & 100 & \\
\hline \multirow{2}{*}{$\begin{array}{l}\text { Teachers use different evaluation } \\
\text { techniques during teaching. }\end{array}$} & Responses & 188 & 150 & - & 37 & - & 375 & \multirow{2}{*}{$414.5^{*}$} \\
\hline & Percentage & 50.13 & 40 & - & 9.86 & - & 100 & \\
\hline \multirow{2}{*}{$\begin{array}{l}\text { Teachers use different motivational } \\
\text { techniques. }\end{array}$} & Responses & 125 & 210 & - & 34 & 6 & 375 & \multirow{2}{*}{$396.3 *$} \\
\hline & Percentage & 33.33 & 56 & - & 9.06 & 1.6 & 100 & \\
\hline \multirow{2}{*}{$\begin{array}{l}\text { Teachers award marks in the } \\
\text { examination fairly to all the students. }\end{array}$} & Responses & 248 & 127 & - & - & - & 375 & \multirow{2}{*}{$660.1^{*}$} \\
\hline & Percentage & 66.13 & 33.86 & - & - & - & 100 & \\
\hline \multirow{2}{*}{$\begin{array}{l}\text { Teachers participate in co-curricular } \\
\text { activities of the university }\end{array}$} & Responses & 53 & 297.0 & 25 & - & - & 375 & \multirow{2}{*}{$813.57 *$} \\
\hline & Percentage & 14.13 & 79.2 & 6.66 & - & - & 100 & \\
\hline \multirow{2}{*}{$\begin{array}{l}\text { Teachers relate the subject matter with } \\
\text { lives of the students. }\end{array}$} & Responses & 141 & 193 & 41 & - & - & 375 & \multirow{2}{*}{$409.14 *$} \\
\hline & Percentage & 37.6 & 51.46 & 10.93 & - & - & 100 & \\
\hline \multirow{2}{*}{$\begin{array}{l}\text { Teachers treat students without } \\
\text { discrimination. }\end{array}$} & Responses & 175 & 127.0 & 45 & 28 & - & 375 & \multirow{2}{*}{$285.83 *$} \\
\hline & Percentage & 46.66 & 33.86 & 12 & 7.46 & - & 100 & \\
\hline \multirow{2}{*}{$\begin{array}{l}\text { Teachers participate in professional } \\
\text { development activities provided by } \\
\text { different organizations. }\end{array}$} & Responses & 119 & 223.0 & 19 & 14 & - & 375 & \multirow{2}{*}{$484.27 *$} \\
\hline & Percentage & 31.73 & 59.46 & 5.06 & 3.73 & - & 100 & \\
\hline \multirow{2}{*}{$\begin{array}{l}\text { Teachers perform their duty regularly } \\
\text { and punctually. }\end{array}$} & Responses & 225 & 150.0 & - & - & - & 375 & \multirow{2}{*}{$600 *$} \\
\hline & Percentage & 60 & 40.0 & - & - & - & 100 & \\
\hline \multirow{2}{*}{$\begin{array}{l}\text { Teachers focus on character building of } \\
\text { the students. }\end{array}$} & Responses & 141 & 215.0 & 19 & - & - & 375 & \multirow{2}{*}{$511.22 *$} \\
\hline & Percentage & 37.6 & 57.33 & 5.06 & - & - & 100 & \\
\hline \multirow{3}{*}{$\begin{array}{l}\text { Teachers use different techniques such } \\
\text { as observation, rating scale, peer } \\
\text { appraisal and check list for assessing } \\
\text { the students. }\end{array}$} & Responses & 110 & 131.0 & 74.00 & 60 & - & 375 & $153 *$ \\
\hline & Percentage & 29.33 & 34.93 & 19.73 & 16 & - & 100 & $136.153^{\circ}$ \\
\hline & Responses & 110 & 131.00 & 74 & 60 & - & 375 & $136.153 *$ \\
\hline
\end{tabular}

* Significant

$\mathrm{df}=4$

Table value $\mathrm{x}^{2}$ at 0.05 level $=9.488$

Table 2 shows that $x^{2}$ values of the responses of students are greater than the table values at 0.05 level of probability. Hence, all the statements are accepted. Analysis of Table 2 of the student's intention showed that the teacher related the subject matter with the lives of the students. Teachers gave individual attention to their spare time and they provided relevant information to explain the points of the subject matter to the students. Teachers also showed appreciation to the students with kind words when they performed well in class. While teaching, teachers used reference books, prepared notes, and encouraged students to participate in co-curricular activities. Teachers also focused on character building of the students and gave feedback with constructive criticism. Different assessment techniques, such as an observation, rating scale, peer appraisal, and check-lists, were used to assess the students. 
Table 2: Responses of Students

\begin{tabular}{|c|c|c|c|c|c|c|c|c|}
\hline \multirow{3}{*}{$\begin{array}{l}\text { Teachers give students individual } \\
\text { attention in their spare time, and } \\
\text { suggest something nice. }\end{array}$} & & SA & $\mathbf{A}$ & UD & DA & SDA & Total & $x^{2}$ \\
\hline & Responses & 408 & 691 & 130 & 09 & 262 & 1500 & \multirow{2}{*}{$931.89 *$} \\
\hline & Percentage & 27.2 & 46.06 & 8.66 & 0.6 & 17.46 & 100 & \\
\hline \multirow{2}{*}{$\begin{array}{l}\text { Teachers provide relevant information } \\
\text { to explain the points of subjects matter } \\
\text { to the students. }\end{array}$} & Responses & 333 & 984 & 59 & 36 & 88 & 1500 & \multirow{2}{*}{$2194.21 *$} \\
\hline & Percentage & 22.2 & 65.6 & 3.93 & 2.4 & 5.86 & 100 & \\
\hline \multirow{2}{*}{$\begin{array}{l}\text { Teachers appreciate students with good } \\
\text { words, when they perform well in the } \\
\text { class. }\end{array}$} & Responses & 739 & 528 & 78 & 122 & 33 & 1500 & \multirow{2}{*}{$1323.2 *$} \\
\hline & Percentage & 49.22 & 35.2 & 5.2 & 8.13 & 2.2 & 100 & \\
\hline \multirow{2}{*}{$\begin{array}{l}\text { Teachers like some students and favour } \\
\text { them unduly. }\end{array}$} & Responses & 330 & 510 & 283 & 225 & 152 & 1500 & \multirow{2}{*}{$298.97 *$} \\
\hline & Percentage & 22 & 34 & 18.86 & 15 & 10.13 & 100 & \\
\hline \multirow{2}{*}{$\begin{array}{l}\text { During teaching teachers use reference } \\
\text { books and prepared notes. }\end{array}$} & Responses & 305 & 794 & 151 & 143 & 107 & 1500 & \multirow{2}{*}{$1093.853^{*}$} \\
\hline & Percentage & 20.33 & 52.93 & 10.06 & 9.53 & 7.13 & 100 & \\
\hline \multirow{2}{*}{$\begin{array}{l}\text { Teachers encourage students for co- } \\
\text { curricular activities. }\end{array}$} & Responses & 543 & 407 & 197 & 153 & 200 & 1500 & \multirow{2}{*}{$651.71 *$} \\
\hline & Percentage & 36.2 & 27.13 & 13.13 & 10.2 & 13.33 & 100 & \\
\hline \multirow{2}{*}{$\begin{array}{l}\text { Teachers use different teaching } \\
\text { techniques. }\end{array}$} & Responses & 411 & 695 & 289 & - & 105 & 1500 & \multirow{2}{*}{$988.3^{*}$} \\
\hline & Percentage & 27.4 & 46.33 & 19.26 & - & 7 & 100 & \\
\hline \multirow[t]{2}{*}{ Teachers are punctual in their duties. } & Responses & 638 & 512 & 183 & 50 & 117 & 1500 & \multirow{2}{*}{$896.21 *$} \\
\hline & Percentage & 42.53 & 34.13 & 12.2 & 3.33 & 7.8 & 100 & \\
\hline \multirow{2}{*}{$\begin{array}{l}\text { Teachers make classroom environment } \\
\text { conducive for the learning. }\end{array}$} & Responses & 200 & 813 & 437 & 26 & 24 & 1500 & \multirow{2}{*}{$1477.29 *$} \\
\hline & Percentage & 13.33 & 54.2 & 29.13 & 1.73 & 1.6 & 100 & \\
\hline \multirow{2}{*}{$\begin{array}{l}\text { Teachers focus on character building of } \\
\text { the students. }\end{array}$} & Responses & 296 & 509 & 418 & 221 & 56 & 1500 & \multirow{2}{*}{$411.313^{*}$} \\
\hline & Percentage & 19.73 & 33.93 & 27.86 & 14.73 & 3.73 & 100 & \\
\hline \multirow{2}{*}{$\begin{array}{l}\text { Teachers give feed back to the students } \\
\text { with constructive criticism }\end{array}$} & Responses & 209 & 540 & 501 & 250 & - & 1500 & \multirow{2}{*}{$662.6^{*}$} \\
\hline & Percentage & 13.93 & 36 & 33.4 & 16.66 & - & 100 & \\
\hline \multirow{2}{*}{$\begin{array}{l}\text { Different assessment techniques such } \\
\text { as observation, rating scale, peer } \\
\text { appraisal and checklist are used for } \\
\text { assessing the students. }\end{array}$} & Responses & 223 & 777 & 350 & 56 & 94 & 1500 & \multirow{2}{*}{$1126.42 *$} \\
\hline & Percentage & 14.86 & 51.8 & 23.33 & 3.73 & 6.26 & 100 & \\
\hline \multirow{2}{*}{$\begin{array}{l}\text { Teachers summarize establishing link } \\
\text { between the present learning with } \\
\text { earlier as well as future learning, } \\
\text { creating a sense of achievement. }\end{array}$} & Responses & 290 & 810 & 300 & 100 & - & 1500 & \multirow{2}{*}{$1300.66^{*}$} \\
\hline & Percentage & 19.33 & 54 & 20 & 6.66 & - & 100 & \\
\hline
\end{tabular}

$\begin{array}{lll}* \text { * Significant } & \mathrm{df}=4 & \text { Table value } \mathrm{x}^{2} \text { at } 0.05 \text { level }=9.488\end{array}$

\section{DISCUSSION}

The majority of teachers opined that they felt proud to be a teacher. They adjusted themselves with the prevailing situation and circumstances of the university. They improved their knowledge and skill through participating in professional development activities and they adequately prepared their lesson before going to the class daily.

The majority of both teachers and students agreed that the teachers used different motivational techniques, such as observation, rating scale, peer appraisal, and check-lists to assess the students. Teachers also used different teaching techniques to make teaching effective. Teachers listened to the students with patience and tolerance and guided them in their spare time. Both students and teachers agreed that teachers awarded marks in examinations without discrimination, they made students participate in co-curricular activities, and gave feedback to the students with constructive criticisms. Teachers expressed that they focused on character building of the students and they showed their intention by relating the subject matter to the lives of the students.

The majority of students pointed out that their teachers provided relevant information while explaining the points of subject matters to them. They also expressed that their teachers appreciated them with kind words about their good performance. Their teachers used reference books and prepared notes and they made the classroom 
environment conducive to learning by establishing a link between present and future learning, creating a sense of achievement.

The relationship between the teacher's behaviour and corresponding academic achievement (marks) of the students revealed that there was highly positive significant correlation between the bahviour of teachers with the academic achievements of students. The higher positive behaivour of teachers towards their students led to the higher academic achievement of the students

\section{AUTHOR INFORMATION}

Syed Shafqat Ali Shah is a $\mathrm{PhD}$ (Education) Scholar at the University Institute of Education and Research, University of Arid Agriculture, Rawalpindi, Pakistan.

\section{REFERENCES}

1. Derk, R. 1974. Educational Technology in Curriculum Development. Harper and Row Publications, New York. U.S.A. P. 19

2. Gauthier, D., M. Loranger and R. Ladouceur. 1984. The Reinforcement of Academic Behaviour: An economic strategy on the intervention of a scholastic environment. P.14, 22.

3. Holpur, G. and P. Helen. 1986. Accommodating instruction to Learner's field independence dependence: a study of effects on achievement and attitudes Perceptual \& Motor Skills, 62 (3):967-974.

4. Iqbal, Z. 1996. Teacher's Training. Institute of Policy Studies and International Institute of Islamic Thought. Islamabad, Pakistan. P. 19.

5. Joyce, B. 1980. Models of Teaching. Printice Hall Co., Englewood Cliffs. U.S.A. pp. 307-308.

6. Karnes, F. A., J. E. Whorton and B. B. Curries. 1984. Correlations between WISC. R. IQs and wide range Achievement Test grade equivalents for Intellectually Gifted students. Psychological of Reports, 54:69-70.

7. Kohli, T. K. 1975. Characteristic Behavioural and Environmental correlates of Academic Achievement of over and Under Achievers at different levels of intelligence. Punjab University, unpublished Ph.D. Thesis. P. 48.

8. Reis G., M. Hahn and D. Barkowski. 1984. The Development of Achievement related level of Aspiration and Self-evaluation in Primary school. Psychologies in Erziehung and Unterricht, 31(3):188-196.

9. Taneja, R. P. 1989. Anmol's Dictionary of Education. Anmol Publications New-Delhi, India. P. 5, 22, 122.

10. Thorndike, R. L. 1963. "The Concepts of Over-and Under Achievement". New York, Bureau of Publications, Teacher's College, Columbia University. P.322.

11. UNESCO. 1975. Report of International Conference of Education. UNESCO Press, Janeva. P. 87.

12. UNESCO. 1986. Glossary of Educational Technology Terms. UNESCO. Pairs. P.18, 59. 
NOTES 